\title{
WISDOM IN THE PROCESS OF HUMANIZING CULTURE. SOME THOMISTIC INSIGHTS
}

\author{
Piotr Roszak
}

Nicolaus Copernicus University

Toruń, Poland

piotrroszak@umk.pl

\author{
UDK: 2-18:008]27-732.3 II Vatikanski \\ $2: 2736 \mathrm{TOM}$ \\ https://doi.org/10.34075/cs.55.4.10 \\ Pregledni znanstveni rad \\ Rad zaprimljen 06/2020.
}

\begin{abstract}
In the light of Vatican II, the Christian contribution to contemporary culture can be characterized by the sapiential approach. Having determined the main obstacle or traps of the current cultural situation, as reported by $B$. Welte in terms of "unwesen", this paper proposes the recovery of wisdom as the ultimate horizon of human activities. This approach can be developed in three ways, according to Aquinas' characteristics of wisdom: enlargement of perspectives, ordering of the big picture and tasting which consists in restoring the distorted taste of things. Finally, possible conclusions for the Christian presence in the world are proposed.
\end{abstract}

Keywords: Thomas Aquinas, Wisdom, Culture, Providence, Metaphysics

\section{INTRODUCTION}

In 2016, in the homily in Santa Marta Pope Francis said that faith transforms in culture only when it is a culture of encounter. ${ }^{1}$ The Pope's call can be interpreted as an encouragement for Christians that they should not abandon their concern for culture. Faith expresses itself in a form of culture and is not able to grow in certain cultures, particularly those which are shaped by materialism. If faith does not fall within such cultural coordinates, then it must either give up or transform culture, because it cannot be practiced on a copy-paste basis, without taking into account the "cultu-

1 Pope Francis, Morning Meditation in the Chapel of the Domus Sanctae Marthae, For a culture of encounter Tuesday, 13 September 2016, http://www.vatican.va/content/francesco/en/cotidie/2016/documents/papa-francesco-cotidie_20160913_for-a-culture-of-encounter.html [access: 27.02.2020]. 
ral cloth" that the faith always has. ${ }^{2}$ The history of ancient cultures with which Christianity interacted confirms this point: the authentic elements of these cultures have remained assimilated, and the rest is permeated with a new spirit of the Gospel. ${ }^{3}$ It is worth indicating that the Christian encounter with Greek metaphysics, which was not a simple absorption of the ancient philosophical wisdom (its vocabulary), a certain infusion of the Gospel into cultural templates, but a broadening of the possibilities of metaphysics itself. ${ }^{4}$

Therefore, culture is not something already given in its finished form, but it is in fieri. ${ }^{5}$ For Christians, this implies an attitude of shaping it, not evaluating it from outside or constructing counter-proposals (if we do not accept it for some reasons). The spirit of the Second Vatican Council goes precisely in opposite direction: it is an invitation to exercise an inclusive role. Somehow, this can be seen as related to our Christian calling for imitation of Christ who stands at the door and knocks (Rev 3:20): it is a desire to be a guest, to be accepted, because we possess a unique gift that we would like to share with other people. This is a starting point of our reflection on how Christians shape cultures of the place where they live.

The aim of this paper, inspired by St. Thomas Aquinas, consists in showing the possible Christian contribution to contemporary culture based on the necessity of wisdom in order to avoid the experience of "non-essence" (unwesen), which characterized the contemporary cultural phenomena. This term introduced by Bernhard Welte describes numerous phenomena that are exposed to a slow shifting of interest from what is significant to what is marginal. ${ }^{6}$ This occurs when the central truth is displaced by the truths located on the peripheries.

2 Pope Francis, Evangelii Gaudium no. 117.

3 Joseph Ratzinger, Truth and Tolerance: Christian Belief and World Religions, Ignatius, San Francisco, 2004. See also Paul O’Callaghan, Cultural challenges to faith: a reflection on the dynamics of modernity, Church, Communication and Culture 1 (2017), 25-40.

4 Matthew Levering, God and Greek Philosophy in Contemporary Biblical Scholarship, Journal of Theological Interpretation 2 (2010), 169-186. See also: Piotr Roszak, Language, Metaphysics and the Bible. The Philosophical Background of Aquinas's exegesis of Sacred Scripture, European Journal of Science and Theology 5(2018), 123-135; Piotr Roszak, Jörgen Vijgen (eds), Towards A Biblical Thomism. Thomas Aquinas and the Renewal of Biblical Theology, Eunsa, Pamplona, 2018.

5 See Enrique Alarcón, Naturaleza y cultura en santo Tomás de Aquino, Revista Española de Teología 3(2019), 397-405.

6 Berndard Welte, Filozofia religii, Znak, Kraków, 1996, 241. 


\section{Wisdom and Culture: What Might the Christian CONTRIBUtion Be?}

As Alister McGrath observes, the current discussion about the origin and nature of human culture is influenced by Darwinism, seeing it as a cumulative progress based on natural selection. ${ }^{7}$ However, there is an agreement that human culture manifests itself by the fact that we are capable of rebellion against a genetic tyranny, like no other species. ${ }^{8}$ Culture remains a school of freedom, shaping the world of human goals. It is freedom that is not an absolute category ("nominalistic"9), comprehended as an unlimited choice: it does not matter if it is good choice or bad one, but the pursuit of good and human development. If freedom is auto-determination, to be causa sui, we are free when we dominate our acts and not act upon other realities. In this sense, the freedom is related to act per se, what was associated with term perseitas. This second ("thomistic") concept means that we are not less free because we have something to eat and drink (we have no choice), but "how" we do this left for us to decide. To be free consists in following the true good and be able to auto-determination. ${ }^{10}$

Asking for hospitality in contemporary culture, Christians bring evangelic wisdom to this world. It is not simply the intellectual erudition, but the knowledge of reality through its ultimate causes (per

7 In this sense, it is worthy to remind following Benno van den Toren, Original Sin and the Coevolution of Nature and Culture, in: S. P. Rosenberg et all (eds), Finding Ourselves after Darwin, Baker Academic, Grand Rapids 2018, p. 178179: „The fact that we share 98.6 percent of our DNA with chimpanzees does not mean that we are no different from apes, any more than the fact the computer chips are made of silicon means that they are no different from desert sand. We may share much of our biological nature with apes, but our unique identity is formed by being advanced cultural beings". See also Javier Novo, Evolución. Para creyentes y otros escépticos, Rialp, Madrid, 2018, p. 111-115, where he indicated the origin of humanity can be related to symbolic language 300.000 years ago. This does not change the fact, as he notes, that human race appeared in the world without noise, quietly. And as God loves every child from the beginning of his existence, before he reaches rationality, so God loved mankind from the beginning in his evolutionary path.

8 Alister McGrath, The Order of Things: Explorations in Scientific Theology, Blackwell, Oxford, 2006, p. 133.

9 This distinction was developed by Servis-Theodore Pinckaers in his Sources of Christian Ethics, CUA Press, Washington, 1995.

10 Bartosz Adamski, Wolność w Chrystusie: aktualność nauczania św. Tomasza z Akwinu o wolności chrześcijańskiej na podstawie piątego rozdziału Super Epistolam B. Pauli ad Galatas Lectura, Biblica et Patristica Thoruniensia 3(2015), 15-25. 
ultimas causas). ${ }^{11}$ This wisdom is possible to acquire in twofold way: the first one is described as per modum cognitionis or perfectum usum rationis ${ }^{12}$ that indicates the human effort to understand reality through causes, dependencies among beings. ${ }^{13}$ Getting to know the world better from the perspective of its end, the ultimate reasons, man becomes wise. It's a way of building education based on a culture of explaining "why" things happen this way and not only "how". ${ }^{14}$ The second was per inclinationem or connaturalitatem and it includes the affective manner of knowing things which is possible when one stays with wise man, because the proximity of nature (and more when occurs the union, which is the consequence of love) make possible the access to the knowledge of things. ${ }^{15}$

There are three consequences for the culture itself, which illustrate the possible fields/areas of cooperation between Christians and any forms of culture. It is particularly important in contemporary culture, which in R. Sala's description has five phrases: antiPlatonic (related to F. Nietzsche), anti-ideological (not for one science that would have the ambition to describe everything), anti-Aristotelian (not for purposefulness nature), anti-Augustinian (not for sacrifice of oneself, but rather self-realization), anti-Roman (loss of trust

11 Enrique Martinez, Fe y contemplación en santo Tomás de Aquino, Revista española de teología, 1(2013),81-95. See also a brilliant thomistic reflection on the processuality of Divine Wisdom in its communication to the creatures: S.-T. Bonino, The Incomprehensible Wisdom of God in the Expositio super Iob, in: Reading Job with Thomas Aquinas, ed. M. Levering, P. Roszak, J. Vijgen, CUA Press, Washington, 2020, 93-126.

12 See André Hayen, San Tommaso d'Aquino e la vita della Chiesa oggi, Jaca Book, Milano, 1967, who claimed that these two expressions are not identical.

13 Tomas Aquinas, Summa theologiae, q. 1 a. 6 ad 3: „Ad tertium dicendum quod, cum iudicium ad sapientem pertineat, secundum duplicem modum iudicandi, dupliciter sapientia accipitur. Contingit enim aliquem iudicare, uno modo per modum inclinationis, sicut qui habet habitum virtutis, recte iudicat de his quae sunt secundum virtutem agenda, inquantum ad illa inclinatur, unde et in $\mathrm{X}$ Ethic. dicitur quod virtuosus est mensura et regula actuum humanorum. Alio modo, per modum cognitionis, sicut aliquis instructus in scientia morali, posset iudicare de actibus virtutis, etiam si virtutem non haberet".

14 See Alfredo Marcos, Moisés Pérez Marcos, Meditación de la naturaleza humana, BAC, Madrid, 2018, 277-325.

15 Tomas Aquinas, Summa theologiae, II-II, q. 45 a. 2c. "Respondeo dicendum quod, sicut supra dictum est, sapientia importat quandam rectitudinem iudicii secundum rationes divinas. Rectitudo autem iudicii potest contingere dupliciter, uno modo, secundum perfectum usum rationis; alio modo, propter connaturalitatem quandam ad ea de quibus iam est iudicandum". See Tomasz Huzarek, Tomasza $z$ Akwinu teoria afektywnego poznania Boga oraz jej filozoficzne i teologiczne zatożenia, Towarzystwo Naukowe KUL, Lublin, 2012. 
in institutions). ${ }^{16}$ Thus the question that should be asked is: "What can wisdom offer to contemporary culture?"

\section{1. "Enlargement" - Seeing the World in a Macro-Perspective}

Seeing the reality from the perspective of ultimate causes, means the ability to describe and act in the world from a macro perspective. ${ }^{17}$ Knowledge of the ultimate goal to which the action is directed, helps people to make good decisions and guide them in the world. The complexity of the world requires the broad horizon. Related processes demand a view from the perspective of the goal that motivates action and makes it easier to get out of the situation where focus on detail obscures the whole picture. This can be compared to someone standing in front of a brilliant painting (e.g. a masterpiece of Rembrandt). We can imagine that he/she knows every $\mathrm{cm}^{2}$ of canvas perfectly, but he/she does not know what the painting is about. Modern science provides a multitude of information about the world, it is able to describe the phenomena in detail, conducting research from a perspective that the philosophy of science defines as bottom-up. The wisdom, on the contrary, introduces the top-down approach, which will not replace the former one, but harmonize and purify both in order to offer a new perspective.

This kind of sapiential enlargement has practical consequences. Contemporary culture, as Taylor has shown in his text entitled A Secular Age, established the "immanent framework" which consisted in reducing our reality only to some internal dimensions. ${ }^{18}$ This, in turn, led to the deactivation of many important goods transmitted historically by culture and religion. They have not disappeared from the world, they are still there, but they are inactive. Like a creditcard before its first use. Expanding and humanizing culture can be based on bringing them back into circulation so that they continue to generate a creative and broad view of the world. Expanding

16 Rossano Sala, Lo Humano posible. Anunciar a Jesucristo en la posmodernidad, in: Gabriel Richi Alberti, Anunciar a Jesucristo en la posmodernidad. A Cincuenta Años de mayo del 68, Universidad San Dámaso, Madrid, 2018, p. 204-208.

17 Thomas Aquinas, Contra Gentiles, lib. 1 cap. 1 no. 3. "Nomen autem simpliciter sapientis illi soli reservatur cuius consideratio circa finem universi versatur, qui item est universitatis principium; unde secundum philosophum, sapientis est causas altissimas considerare."

18 See Charles Taylor, A Secular Age, Belknap Press of Harvard University Press, Cambridge, Mass., London 2007, 143. See also: Krzysztof Pilarz, Sekularyzacja sacrum i jej konsekwencje pastoralno-wychowawcze, Teologia $i$ Człowiek 28(2014)4, 11-25. 
consists precisely in building imagination that shows possible worlds. Deactivation of these goods in cultural history was sometimes a gradual process or in some cases a revolutionary one, but the lack of them is a sign of the impossibility of choosing and making the macro decisions we have to take. The development of science, which is actually based on induction (not deduction as it was in premodern era), requires a new synthesis at some stage. Christianity offers a big/broad framework, it extricates culture from entanglement of immanentism, offering fresh imagination of new possible ways. This is perfectly expressed in the thought of Gaudium et Spes 15:

The intellectual nature of the human person is perfected by wisdom and needs to be, for wisdom gently attracts the mind of man to a quest and a love for what is true and good. Steeped in wisdom man passes through visible realities to those which are unseen. Our era needs such wisdom more than bygone ages if the discoveries made by man are to be further humanized. For the future of the world stands in peril unless wiser men are forthcoming.

This is actually a basic feature of Christian wisdom, which expresses the essence of Catholicism: thinking on the whole, judging from the perspective of the whole, not choosing one at the cost of the other, but the ambition to find a place for everyone, not sacrificing other things on the altar of progress. ${ }^{19}$ The Christians believe it can be done. This Christian attitude is reflected in many cathedrals and at universities - demonstrating a universal ambition of Christian faith.

\section{2. "Ordering": to Discover the 'Big Picture'}

Another function of wisdom, as Aristotle emphasized, is ordering: sapientis est ordinare. ${ }^{20}$ Introducing order in the world is not, however, similar to cleaning the apartment, only an aesthetic housework, but managing individual matters due to their final goal.

19 See H. de Lubac, Catholicism: Christ and the Common Destiny of Man, Ignatius, San Francisco 1988.

20 Thomas Aquinas, Contra Gentiles, lib. 2 cap. 24 no. 4. „Secundum philosophum, in: I Metaph. ordinare sapientis est: ordinatio enim aliquorum fieri non potest nisi per cognitionem habitudinis et proportionis ordinatorum ad invicem, et ad aliquid altius eius, quod est finis eorum; ordo enim aliquorum ad invicem est propter ordinem eorum ad finem. Cognoscere autem habitudines et proportiones aliquorum ad invicem est solius habentis intellectum; iudicare autem de aliquibus per causam altissimam sapientiae est." 
It reminds, as Irenaeus of Lyon suggested, the process of creating stone mosaic: someone who knows the final pattern can do it very well. ${ }^{21}$ It is difficult to assemble a puzzle consisting of 1,000 parts if you do not know the image you want to arrange. It will not appear randomly.

Seeing the world as an order, an ordo, and thus as whole composed by different, mutually related, parts, entails two focal ellipses: the multiplicity of beings and the rule or principle according to which they are assigned to each other. Besides, the internal relation among beings depends on fundamental relation of the whole to the final end. ${ }^{22}$ Thus it is not about eliminating connections, reducing everything to one "allowed" manifestation. The culture for Christians consists in developing relations among people and their actions, leading them to flourishing as the ultimate goal. ${ }^{23}$ This corresponds specifically to the Christian understanding of culture as a relation of man to arche, and to the origin from where we depart, and to telos, and therefore to the purpose of our existence.

This possible contribution of Christians, consisting in the fact that they do not build their own cultural elite, but make an effort in discovering and nurturing this ordo ad invicem, resembles the mythological thread of Ariadne in the maze of modernity. ${ }^{24}$

\section{3. "Tasting": to Restore the Distorted Taste of Things}

Wisdom concerns the knowledge of truth (in thomistic tradition sapientia is an intellectual virtue), but it remains in relation to the affective dimension. That is why, wisdom is for Aquinas a "tasty knowledge" (sapida scientia), because it saturates man's will and desires. ${ }^{25}$ Christians bring a taste to culture that is associated with dynamic perception of wisdom, not as fossilized encyclopedic knowledge, but as a chance to discover the world in all its dimension. In one of his biblical commentaries, Aquinas compares it to the

21 See A. M. McCoy, The Irenaean Approach to Original Sin through Christ's Redemption, in: S. P. Rosenberg et all (eds), Finding Ourselves after Darwin, Baker Academic, Grand Rapids 2018, 160-172.

22 Thomas Aquinas, Contra Gentiles, lib. 2 cap. 24 no. 4.

23 Michał Zembrzuski, Mądrość, kontemplacja, syndereza i sumienie w etyce Tomasza z Akwinu, Edukacja Filozoficzna 67 (2019), 155-179.

24 Charles Taliaferro, The Golden Cord: A Short Book on the Secular and the Sacred, Notre Dame, in: Notre Dame University Press, 2012.

25 Thomas Aquinas, Summa Theologiae, I, q. 43 a. 5 ad 2; Cfr. Thomas Aquinas, In II Cor., cap. XIII, lect. 3. 
smell of baking bread: ${ }^{26}$ wise people bring this specific smell into the world.

St. Thomas utilizes this culinary comparison when he speaks of original sin, and therefore evil, which has disordered human life. He compares its effects to a situation when someone has lost their taste and begins to enjoy things that should disgust him. In his commentary on the Letter of St. Paul to the Romans, we can read the following words on how grace changes the manner of perceiving reality:

"It should be noted that just as a person with a diseased palate misjudges the taste of foods and sometimes recoils from the tasty but approves the disgusting, whereas a person with a healthy palate judges tastes correctly; so a person whose affections are corrupted by conformity to worldly things misjudges the good, whereas a person whose affections are upright and sound, his sense having been renewed by grace, judges the good correctly." 27

Christians offer exquisite "food", also spiritual, which demands the specific art of eating (imagine frutti di mare, you need to know what cutlery to use). How to restore the lost taste? Eating good things... offering to culture something worthy to be known, to be followed, and to be loved. This is what Christian can contribute to the complicated situation of contemporary culture, showing what is really worthy to be desired and offering meaning of human activities. ${ }^{28}$

Tasting the world is not only an interest in what is worthy of love and truly good, but a specific way to explore the world. In Summa contra gentiles, in the introduction to the second book about God's action and His government over the world, St. Thomas, first, justifies why it is worth investigating and knowing the creation, that is temporal and limited. The last, fourth argument indicates that by knowing the world in the light of God, or through His prism, which is realized through the virtue of faith, man imitates God's perfection. ${ }^{29}$ It is God who knows everything through Himself, and theology

26 Thomas Aquinas, In I Cor., cap. V, lect. 2.

27 Thomas Aquinas, In Rom., cap. XII, lect. 1 (no. 967). Translation by F. R. Larcher $\mathrm{OP}-$ see St. Thomas Aquinas, Commentary on the Letter of Saint Paul to the Romans, ed. J. Mortensen and E. Alarcón, The Aquinas Institute for the Study of Sacred Doctrine, Lander WY, 2012.

28 See Lluis Oviedo, Meaning and Religion: Exploring Mutual Implications, Scientia et Fides 1(2019), 25-46.

29 Thomas Aquinas, Contra Gentiles, lib. II, cap. 2. 
as sacra doctrina is an encouragement to read the world in such a way as not to lose references to the Creator. ${ }^{30}$ Faith is not only an expression of views (as it would be a mere "opinion" 31 ), but a way of God's imitation and the beginning of eternal life. ${ }^{32}$ From this flows a specific project of Christian humanism, which does not have to face a false alternative, God or man, because they belong to different causal and ontological realities, but it consists in the right order. Christian wisdom leads us to see the world as a whole. It is not worthy to contemplate only a small piece of a painting, even if we know a lot about its $\mathrm{cm}^{2}$, but the part gains its meaning when placed in a wider, universal order. It is extremely important for St. Thomas, to lead this reflection: to see two types of orders, one transcendental (good outside the world), and the other internal, relations between things. ${ }^{33}$ The former is a condition of the latter, so thinking about what is outside or transcendental is crucial for the internal or immanent system. Wisdom can be characterized as a precise orientation in these orders and culture as something able to visualize these dependencies of different orders (which also include what is accidental, because order does not signify automatism). In this perspective, the expression of such wisdom could be the theological virtue of faith, which is not "dealing with trouble" (as many naturalists perceive faith today in terms of adapting the mechanism), but faith is the activity that permits obtaining a holistic view, because it remains focused on what transcends our worldly order. ${ }^{34}$ This is one of the questions that appear in the sum of theology when reflecting on faith: why should man believe in what goes beyond what is natural? ${ }^{35}$

30 Cf. Gaven Kerr, Aquinas and The Metaphysics of Creation, OUP, Oxford, 2019, p. 82-86. See also: Piotr Roszak, Revelation and Scripture: Exploring the Scriptural Foundations of sacra doctrina in Aquinas, Angelicum 93 (2016), 191-218.

31 Thomas Aquinas, De Veritate, q.14, a.1.

32 Thomas Aquinas, Summa Theologiae, II-II, q.4, a.1c.: "[...] fides est habitus mentis, qua inchoatur vita aeterna in nobis, faciens intellectum assentire non apparentibus". See also Emilio Justo, Immortal Life and Eternity. On the Transhumanist Project of Immortality, Scientia et Fides 2(2019), 233-246.

33 Thomas Aquinas, Contra Gentiles, lib. II, cap. 24.

34 See Miroslaw Mróz, Physiological and Psychological Foundation of Virtues: Thomas Aquinas and Modern Challenges of Neurobiology, Scientia et Fides 2(2018), 115-128.

35 Thomas Aquinas, Summa Theologiae, II-II, q.2, a.3. 


\section{CONCLUSIONS}

From the beginning, the role of Christians in the world has been illustrated by many convincing images. Two of them are worth mentioning at the end of my paper.

First, I'd like to mention the example of St. Paul who encourages Christians to perceive their mission as being a source of light in the world (Phil 2:15), and thus not separating themselves from culture, but contributing to its development. It consists in helping others to grow: Christians can illuminate life experiences with the light of the Gospel. ${ }^{36}$

The second metaphor originates from the Letter to Diognetus where we read that "the Christian is to the world what the soul is to the body." They are not visible directly, like the soul is invisible to our eyes, but they bring life, because anima is the principle of life that permeates all members and shapes their identity. ${ }^{37}$

Pope Francis draws attention to the need to start processes to renew cultural patterns, in a word, shows Christians as related to the culture in which they live. On the basis of one of ancient myths, he develops a possible and fruitful scenario for Christian culture:

We need to reclaim our right not to be sidetracked by the many sirens that nowadays distract from this pursuit. Ulysses, in order not to give in to the siren song that bewitched his sailors and made them crash against the rocks, tied himself to the mast of the ship and had his companions plug their ears. Orpheus, on the other hand, did something else to counter the siren song: he intoned an even more beautiful melody, which enchanted the sirens. This, then, is your great challenge: to respond to the crippling refrains of cultural consumerism with thoughtful and firm decisions, with research, knowledge and" (Christus vivit, no. 223).

So, Christians can provide a good stimulus for the culture, trying to change it by offering something better, a greater good, not fighting directly with evil (the Incarnation is an example of this divine logic). It is similar to the aircraft that with too low speed will not take off. It requires a good speed to start the journey.

Christians can provide this "speed" to the culture with the emphasis on goal-culture. It is not a solution to freeze culture, adore

36 Piotr Roszak, Credibilidad e identidad. En torno a la teología de la fe en santo Tomas, Eunsa, Pamplona, 2014.

37 Sasa Horvat, Heideggerov posljednji Bog, Bogoslovska smotra, 4 (2017), 745-766. 
one of its historical manifestations (i.e. medieval one), but transform the world by orienting it towards true good, integrating new technological discoveries and revealing their meaning. ${ }^{38}$ It is the hermeneutic mission, which consists in explaining the world, coping with various side effects. We should not create an intellectual ghetto, but try to engage cultural challenges and propose a Christian solution oriented towards the ultimate dimension of human being. ${ }^{39}$

The best confirmation of this role of wisdom in culture can be the greeting formula of medieval pilgrims going to Santiago de Compostela, who repeated: Ultreya! Suseia! Deus adiuva nos, which can be translated into English as to keep going, reaching 'beyond', going higher, God help us. ${ }^{40}$

\section{MUDROST U PROCESU HUMANIZIRANJA KULTURE. NEKI TOMISTIČKI UVIDI}

\section{Sažetak}

Kršćanski doprinos suvremenoj kulturi u svjetlu Drugog vatikanskog koncila može se okarakterizirati mudrosnim pristupom. Određujući glavne prepreke ili zamke trenutne kulturne situacije, kako je Bernhard Welte izvijestio u smislu „ne-biti“ (unwesen), ovaj rad predlaže oporavak mudrosti kao krajnjeg horizonta ljudskih aktivnosti. Ovaj se pristup može razviti na tri načina, u skladu s Akvinčevim karakteristikama mudrosti: proširenjem perspektiva, uređenjem velike slike i degustacijom što se sastoji od popravljanja iskrivljenog ukusa stvari. Konačno, predlažu se mogući zaključci za kršćansku prisutnost u svijetu.

Ključne riječi: Toma Akvinski, mudrost, kultura, providnost, metafizika

38 See Ivan Platovnjak, Tone Svetelj, To Live a Life in Christ's Way: the Answer to a Truncated View of Transhumanism on Human Life, Bogoslovni vestnik/ Theological Quarterly, 3(2019), 669-682.

39 John Berry, Yves Congar's Vision of Faith, GBP, Roma, 2019.

40 See Franciszek Mróz, How has Camino developed? Geographical and Historical Factors behind the Creation and Development of the Way of St. James in Poland, in Enrique Alarcon, Piotr Roszak (eds), The Way of St. James: Renewing Insights. Ediciones Universidad de Navarra, Pamplona, 2017, p. 59-80. See also Piotr Roszak, Camino de Santiago i devotio (post-) moderna. W poszukiwaniu tożsamości pielgrzyma $w$ dobie ponowoczesnej bezdomności, in: Piotr Roszak Waldemar Rozynkowski (eds), Camino Polaco: Teologia-Sztuka-Historia-Teraźniejszość, t.2, Wydawnictwo Naukowe UMK, Toruń, 2015, 219-238. 